\title{
The Effect of Using WhatsApp on the Jordanian 5th Grade EFL Students' Speaking Skill
}

\author{
Amin Ali AlAzzam-Khraiwish (Corresponding author) \\ School of Education, Department of Curricula and Instruction \\ Al al-Bayt University, Mafraq, Jordan \\ E-mail: amin22zn@yahoo.com
}

\begin{abstract}
Ahmed M. Bataineh
School of Education, Department of Curricula and Instruction

Al al-Bayt University, Mafraq, Jordan
\end{abstract}

Ayman H. Alzyod

School of Education, Department of Curricula and Instruction

Al al-Bayt University, Mafraq, Jordan

Received: May 13, 2021

Accepted: July 5, 2021

Published: July 31, 2021

doi:10.5296/ijl.v13i4.18749

URL: https://doi.org/10.5296/ijl.v13i4.18749

\begin{abstract}
The aim of this study is to investigate the effect of using WhatsApp on developing fifth grade EFL students' speaking skill during the first semester of the academic year 2020-2021. To achieve this purpose, the researchers selected carefully a representative sample of 46 male students studying at Jijin Secondary School for Boys. The participants were already divided into two groups; a control group of 21 students and an experimental one of 25 students.

This study tended to apply this experiment by using the quasi-experimental method. The instrument was a performance test in a shape of an interview that was used as a pre-test and a post-test. Moreover, this test was used to measure any possible differences between the both groups. The results of the study indicated that there were statistically significant differences
\end{abstract}


between both of the groups and the mean scores, in favor of the experimental one in speaking due to the suggested strategy of using WhatsApp.

In the light of the findings, the researchers recommend the necessity of implementing contemporary strategies such as WhatsApp in teaching and learning English speaking skill. Besides, the researchers suggest that further studies should be conducted on the effect of WhatsApp on developing other English language skills and in other language competences.

Keywords: EFL, Speaking, WhatsApp, 5th grade students

\section{Introduction}

\subsection{Background of the Study}

With rapid advances and improvements in technology, language learners' interests change and this requires teachers to fetch for more technological methods to attract their attention. There is an important role for technology in language teaching and learning process. It is a fact that technology provides learners with many materials for learning.

Lawrence (2002) argued that technology could facilitate the teaching-learning process and could provide learners to be good self-learners. By using technology, Students are motivated and enthusiast to learn. Many researchers have recommended the learners to watch authentic videos and audio clips to get better language learning. It is recommended that teaching and learning process is a complex unit in which learners as well as teachers should compromise between the regular and the contemporary instruction strategies with help of technology (Maness elt.ccsenet.org English Language Teaching Vol. 12, No. 6; 2019192 2004). Hamad M. Mona (2017) studied WhatsApp as useful way to enhance students' learning and excitement, and to improve self-learning skills. Many types of documents could be sent via WhatsApp to the students so that the learning materials are available to them.

Recent world has witnessed so many advances and developments in many fields of life and knowledge that require teachers to get benefit of them in the teaching-learning process. They cannot just stand watching the rapid movement and improvement of the world without using them to help in this process. WhatsApp is one of the most significant ways of communication and learning nowadays. According to (Sharples, Taylor \& Vavooula, 2007) mobiles are being used as a tool for learning as a contemporary creative strategy for teaching and learning. Additionally, they enable students and teachers to participate in lessons and have the learning material outside class hours. So, they facilitate the teaching-learning process. Also, (Laurillared, 2007; Beger \& Sinha, 2012) and (Uys et al, 2012) state that undergraduate students could utilize their time of using mobiles in learning and self-learning.

WhatsApp is used in Teaching English for many reasons: firstly, WhatsApp can economize in time reaching a big number of students. They can easily have their discussions and dialogues on certain topics by using such application (Trentin \& Repetto, 2013). Secondly, WhatsApp can easily gain students' attention, responsiveness to provide fun-based learning. Students can express their ideas by attaching pictures, sharing videos, Web-links, and videos. 
Students could respond freely, and the teacher respond to students' inquire and comments, starts new issues, or posts queries (Dunlap, 2006).

WhatsApp can be used by students to interact and discuss with each other in several topics they like. It is an online smart phone application which donates users several ways of communication such as group talks, individual chats or WhatsApp calls and enables them to share multimedia files, simple texts, contact numbers or even sharing the location (Anglano, 2014). Students socialize and freely share what is available online for their own exploration and learning (Vygotsky, 1978).

Receptive skills are the ability to understand expressions and words when reading or listening, while productive skills include using the language acquired in spoken form or written one. (Laufer, 1998). The productive and receptive skills are integrated and interwoven; because language is: an ear and an eye then a tongue. Speaking aspects provide speakers with unique chance to communicate effectively; the more the learner practice, the better the language is. WhatsApp could give the learner wonderful results on speaking as "Speaking is a hard skill" (Alonso, 2014, p. 147). Achmad and Yusuf (2014: 153) marked that, WhatsApp is one of those environments that motivate students to be good learners and speakers when teachers are supposed to create communicative environment with motivation to practice the target language in speaking classes.

\subsection{Statement of the Problem}

From the researchers' experience as teachers of English language for about eighteen years, Supervisor, curricula designer, textbook writer and teacher for BA, MA, and $\mathrm{PhD}$, they observed that students in Jordan are continuously facing various problems in learning English language, especially the oral skill. The researchers tried to find new ways of teaching English that help students to have a stimulating, attractive and helpful learning environment through using their smart phones and other technologies that facilitate the learning process naturally.

Accordingly, students should be able to transfer what they learn into actual practice. This study gives the researchers clearly understanding of how WhatsApp could be used inside and outside the classroom, and how this usage might compliment the classroom teaching activities.

\subsection{Purpose of the Study}

The purpose of this study was to investigate the pedagogical effect of WhatsApp on the $5^{\text {th }}$ grade EFL students' speaking skill in English. It also aimed to investigate whether teaching speaking via WhatsApp is better than the regular methods.

\subsection{Significance of the Study}

Many researchers are very interested in using recent strategies for teaching and learning; WhatsApp is one of them. Therefore, many studies have been conducted on using such strategies for teaching English. This study might offer pedagogical benefits for teachers, students, curricula designers as well as textbook writers. It showed the real effect of using WhatsApp for teaching and learning speaking on the previous mentioned stakeholders. It may 
help teachers to decide students' progress and it can encourage better communication and interaction between teachers and students.

Also, WhatsApp could help students study effectively and independently using chat options with good language learners or with native speakers. It might be a step for curricula designers to take towards improving the educational and specific objectives and to improve and enhance our English language textbooks.

\subsection{Question of the Study}

Are there any significant differences between the mean scores of the experimental and control group students' speaking due to the strategy of teaching (Using WhatsApp vs. regular instruction)?

\subsection{Hypotheses of the Study}

There aren't any significant differences between the mean scores of the experimental and control group students' speaking due to the strategy of teaching (Using WhatsApp vs. regular instruction).

\subsection{Limitations of the Study}

The limitations of the study are:

1 Participants of the study are limited to 46, 5th grade male students. A study conducted on a different sample or a bigger number may give different results.

2 The generalizability of the study is limited to the students of the 5th grade in a public school; Jijjin Secondary School for boys in Irbid Directorate of Education during the first semester of the academic year 2020/2021. So, the results can be generalized to similar samples or contexts.

3 The duration of the study lasts for only eight weeks. A longer duration may have different results.

\section{Review of Related Studies}

\subsection{Theoretical Background}

Today, technology seems to have entered in many aspects of life at a large extent. Making communication easier, mobile phones might easily be observed to be the most popular devices used by people in all ages. They have great features and thus are called as smart phones which offer easy communication through internet and enables people a quick access to e-mails or social networking sites (Montag, et al., 2015).

Riyanto (2013) claimed that WhatsApp can be used to study and learn a new language. Students can read and speak English when using WhatsApp, and this improves their English reading and speaking skills. Rambe\& Chipunza (2013) indicates that WhatsApp gave students the possibility to express themselves openly in a free environment considering individual differences and removing the participation hindrances. 
Communication is the basic feature in human beings to fulfill needs in their lives. Using language makes a difference from human communication pattern to other types of communication. Human communication basically starts with practicing and imitating sounds through listening and speaking. The learning process depends on one skill to another; there isn't any skill that is practiced individually. The process of learning a language depends on active skills like listening and speaking, and later it extends by using passive skills like writing and reading. (Khan \& Ali, 2010). Speaking skill is one of the active productive skills. While communicating with others, it is a primary skill. Getting proficiency on the other three skills helps the learner to get knowledge and share ideas through oral communication (Khan \& Ali, 2010).

\subsection{Empirical Studies}

There are many studies on WhatsApp effect on the EFL teaching-learning process. According to Fortunato Escobar and Indira Gómez-Arteta (2020), the aim of the study was to check the effectiveness of WhatsApp as a mobile learning strategy in the development of oral communication skills of secondary level students at the 'José Carlos Mariátegui' educational institution (Puno-Peru). The population was comprised of 343 students and a non-probabilistic with samples that are divided into the experimental group and the control group. The results showed that WhatsApp develops significant oral and written communication skills. Thus, WhatsApp is a mobile learning technology resource available to develop and strengthen skills and knowledge in students.

According to Elhadi Nasr Elhadi Mustafa (2018), the study was attempted to investigate the impact of YouTube, Skype and WhatsApp in improving and enhancing the EFL learners' speaking skill, and to draw the attention toward the importance of these applications in improving English language speaking skill. The aim of this study was to come to light with constructive recommendations for students, teachers and educationists in order to enhance the teaching-learning of spoken English process. In addition, it attempted to focus on learning the speaking skill with help of modern technology. The instrument of this study was a speaking test for (22) students from Arab Open University, Riyadh branch, in the year 2017. The pre-test and post-test were given to students independently in their formal class timetable. After two months training, the same post-test was conducted on the same students. Data was statistically analyzed. Accordingly, Social media networking has an abundant effect on speaking. It also recommends to teachers who wish to improve their students' speaking skill to consider these applications toward the learning process. Finally, the study pointed out that YouTube, WhatsApp and Skype play a great role in improving EFL learners' oral communication skills.

Moreover, according to Conor Keogh and Heydy Robles (2018), the study focused on how WhatsApp technology provides learners of a second language with life-like or real-life situations. The study analyzed the interactions which occur in the group. Data had shown examples of interaction between participants in their second language. Participants' responses indicated positive benefits. The study encouraged discussion, participation and enhanced learner identity. 
A magnificent study by Amir Abdalla Minalla (2018) examined the possibility of employing 'WhatsApp Group' in boosting EFL learners' verbal interaction. Experimental and descriptive methods were used to reach the aims of this study. A pre- post-test was conducted to collect data. The same instructional material has been taught for the experimental and the control groups by using the regular instruction integrated with WhatsApp Chat groups to be practiced outside classroom contexts for what is in the traditional class. However, the participants of experimental group had interactions via voice messages, while the participants of control one interacted only via text messages. The participants who undertook the voice messages on WhatsApp treatment significantly outperformed those who undertook in text messages on WhatsApp. Thus, using voice messages on WhatsApp chat groups could be recommended as an effective strategy in improving and enhancing EFL learners' verbal interactions outside classroom contexts because EFL traditional classroom is no longer more proper for offering sufficient opportunities for EFL learners' verbal interaction.

Alberto Andújar-vaca (2017) conducted a study which investigated the benefits of Mobile Mediated Communication (MMC) for developing oral skills in second-language learners. A total of 80 Spanish students studying a B1 English course at the University of Almería were examined. According to the treatment type, topics were in two groups, experimental and control. A "WhatsApp" group was created with 40 participants in a daily interaction for six months. The speaking samples collected in the application were used to measure the students' degree of oral development and the type of the language given via mobile chat-based oral interaction. The study focused on interaction and tried to measure the students' degree of oral development. Significant improvements in term of oral proficiency were observed in the experimental group. Negotiations were common throughout the included activity. It is deeply believed that Mobile learning offers an environment where learners can actively negotiate meaning, reflect and evaluate on their own performance through authentic and instant interaction and building up a great tool for developing second language proficiency.

Moreover, a related pilot study according to (Deshen et al., 2014) was attempted to explore class communication in shared teacher-student WhatsApp groups. Teachers who use WhatsApp groups together with their students were interviewed in this study. These interviews examined the advantages and disadvantages of these trendy groups. The interviews showed that using WhatsApp is preferable to other media (e-mail, Facebook, and texting). In addition, the teacher's presence in the group has a positive effect on the conversation between the students. This application also lets the student reviews the material at home and gets additional knowledge in addition to the formal classes. Moreover, teachers can correct students' mistakes or errors immediately by adding comments.

\subsection{Concluding Remark}

Like the previous studies, this study focused on studying the effect of using WhatsApp on speaking development. The present and the previous studies affirm that there is a complexed relationship between the success of speaking skill and the strategy used for teaching and learning of this skill; using WhatsApp has a very noticeable effect on learning speaking skill. 
Many studies have found out that WhatsApp groups are used for communicating with students, enhancing a social atmosphere in class, establishing collaboration between the students, and as a strategy of learning. Moreover, there is another benefit of this application which is the possibility it gives the teacher to influence student discourse.

Resorting to such application could improve and facilitate the process of teaching and learning of speaking skill since it is considered as a technological application which is one of the contemporary strategies that clearly and positively affect the learning process of language skills and subskills.

\section{Methods and Procedures}

\subsection{Participants of the Study}

The participants of this study were 46 male students from the $5^{\text {th }}$ grade at Jijin Secondary school in Jordan.

\subsection{Design of the Study}

This study was carried out using the equivalent pre /post-test two-group design. The experiment consisted of two levels: The subjects of the experimental group were exposed to WhatsApp application training for (8) weeks after school lessons. However, the subjects of the control group were exposed to the regular instruction in teaching English speaking by using printed material only for the same period. A pre-test was given before the application of the treatment to the both groups to make sure if they are equivalent and the same test was administered as a post-test after applying the treatment to see whether using WhatsApp application has any influence on the experimental group and which method of instruction has more influence on the subjects than the other.

\subsection{Instrument of the Study}

The researchers applied a pre/post-test technique during this study:

- Pre-test was given before the application of the treatment to know the current actual students' level in speaking.

- $\quad$ Post-test was given after applying the treatment for 8 weeks to see whether WhatsApp has any influence on the experimental groups and which way of instruction has more influence on the subjects than the other.

\subsubsection{Validity of the Test}

The instrument was given to a jury of experts in order to detect the accuracy, clarity, validity and the appropriateness of the instrument to the material of instruction and to the level of the learners. Then, the instrument was modified depending on their highly considered recommendations. 


\section{Macrothink}

\subsubsection{Reliability of the Test}

To establish the reliability of the instrument, the researchers used the test- retest on a pilot study with a two week period between the test and retest.

\subsection{Variables of the Study}

The independent variables of this study were:

1) Teaching method which includes:

2) Teaching speaking via WhatsApp

3) Teaching speaking with regular instruction

4) Training technique which included:

5) Individual

6) Pair work

7) Group work

8) The dependent variable of this study was students' performance and their scores in speaking test.

\subsection{Instructional Material}

Speaking lessons represented with a printed form were taught for the control group by using the regular form of instruction. While the same printed material was practiced by using WhatsApp for the experimental one after they were back home to practice these areas of the material and make discussions with colleagues in an oral form.

\subsection{Procedures of the Study}

This study was adapted during the first semester of the academic year 2020-2021 at Jijin Secondary School for boys. The following procedures were followed after the researchers had the approval letter from the First Directorate of Education in Irbid to conduct this study.

1. Jijin Secondary School was chosen to apply this study.

2. Fifth grade students who study at Jijin Secondary School were purposefully chosen for logistic purposes as a sample of the study.

3. The sample of the study was already divided by the school administration into two sections: $\mathrm{A}$ and $\mathrm{B}$; $\mathrm{A}$ is the experimental group and $\mathrm{B}$ is the control one.

4. The researchers explained and clarified the nature of the study to the students.

5. A pre-test was conducted to both groups' students to make sure that there were no significant differences between the two groups in their level of speaking. 


\section{1) Macrothink}

International Journal of Linguistics

ISSN 1948-5425

2021, Vol. 13, No. 4

6. Students in both groups sat to a speaking test in a form of interview at the beginning of the first semester of the academic year 2020-2021 to determine their speaking level before starting the experiment.

7. The material was taught five times a week for each group for a period of 8 weeks to practice speaking.

8. The experimental group exposed to the same syllabus used for teaching the control group by using WhatsApp, whereas the control group studied regularly.

9. A post-test was administrated to both experimental group and control group after the application.

10. Students' results were sent to a statistician to analyze according to the descriptive statistical methods (means, standard deviation and T- test)

\section{Findings of the Study}

\subsection{Equivalence of the Two Groups}

Pre speaking test in a form of interview was administrated to both groups to identify the actual level of the students before starting the experiment, means, standard deviations and t-test were used to find out any significant differences between both groups of the study, as shown in the table below.

Table 1. Means, standard deviation and t-test results of the experimental and control groups on the pre speaking test

\begin{tabular}{llllllll}
\hline & GROUP & $\mathrm{N}$ & Mean & Std. Deviation & $\mathrm{T}$ & DF & Sig. (2-tailed) \\
\hline $\begin{array}{l}\text { PRE } \\
\text { TEST }\end{array}$ & Experimental & 25 & 43.16 & 12.332 & .547 & 6 & .637 \\
\hline & & Control & 21 & 42.37 & 9.853 & & \\
\hline
\end{tabular}

Table 1 reveals that students' scores for both groups were almost equivalent in pre-test before applying the experiment. This indicated that the two groups were equivalent, before starting the experiment. This also showed that the difference between scores of both groups on the pre Speaking test was not statistically significant.

\subsection{Findings of the Study}

The question was "Are there any significant differences between the mean scores of the experimental and control group students' speaking due to the strategy of teaching (Using WhatsApp vs. regular instruction)?" For answering this question, means, standard deviations of students' speaking of the two groups for the strategy of teaching (Using Website Games vs. regular instruction) and t-test were calculated to find out any significant differences between both groups of the study, as shown in table below. 
Table 2. Means, standard deviation and t-test results of the experimental and control groups on the post speaking test

\begin{tabular}{llllllll}
\hline & GROUP & $\mathrm{N}$ & Mean & $\begin{array}{l}\text { Std. } \\
\text { Deviation }\end{array}$ & $\mathrm{T}$ & DF & $\begin{array}{l}\text { Sig. } \\
\text { (2-tailed) }\end{array}$ \\
\hline POST TEST & Experimental & 25 & 66.91 & 12.539 & 6.276 & 46 & .000 \\
\cline { 2 - 8 } & Control & 21 & 52.08 & 9.977 & & & \\
\hline
\end{tabular}

Table 2 shows that there are statistically significant differences at $(\alpha=0.05)$ between the means of both groups on the post students' Speaking test, in favor of the Experimental group (Using WhatsApp).

\section{Discussion, Conclusion and Recommendations}

\subsection{Discussion of the Results of the Study}

The question of the study investigated if there were any significant differences between the mean scores of the experimental and control group in Speaking due to the strategy of teaching (WhatsApp vs. regular instruction).The findings of the study have revealed that using WhatsApp was a very effective method to develop speaking.

The experimental group students' scores in the post-test were higher than those of the control group. Accordingly, the hypothesis of the study, which reads " There aren't any significant differences between the mean scores of the experimental and control group students' speaking due to the strategy of teaching (Using WhatsApp vs. regular instruction) at $\alpha \leq 0.00$ " was rejected.

Moreover, using WhatsApp can be regarded as an effective method to develop the EFL learners' speaking. These results agree with the results of many studies that tackled many aspects and topics that related to using WhatsApp and its effect on speaking.

The results of the this study go with what was stated and emerged from the studies by Fortunato Escobar and Indira Gómez-Arteta (2020), Conor Keogh and Heydy Robles (2018), Alberto Andújar-vaca (2017), Elhadi Nasr Elhadi Mustafa (2018), Amir Abdalla Minalla (2018), (Deshen et al., 2014) .

\subsection{Conclusion}

It could be concluded that using WhatsApp is very important in teaching English speaking because it can help students to be more confident and fluent since it at least gives the minimal amount of language exposure. Besides, using WhatsApp had a positive effect on EFL learners' speaking. The following conclusions can be derived from this study accordingly:

- Using WhatsApp is advised to be used in teaching speaking.

- Using WhatsApp has more effect on speaking and fluency.

Additionally, it can be concluded that the use of WhatsApp motivates students towards learning, since they spend much time using mobiles and mobile-based applications. This can be utilized for learning EFL. It also enhances the students' learning of speaking in their life- 


\section{Macrothink}

International Journal of Linguistics

ISSN 1948-5425

2021, Vol. 13, No. 4

like situations within contexts. They also facilitate the teacher's job by changing his role from a manager to a director and facilitator.

\subsection{Recommendations}

According to the findings of this study, students, textbook writers, teachers, and researchers are highly recommended to take the following recommendations into consideration to achieve their job successfully:

- Further similar studies on other classes could be conducted in order to make the results more valid and applicable.

- It is recommended to the Ministry of Education to adopt WhatsApp in its curricula.

- It is recommended that the Ministry of Education train teachers on how to utilize WhatsApp in the process of teaching and learning.

\section{References}

Achmad, D., \& Yusuf, Y. Q. (2014). Observing pair-work in an English-speaking class. International Journal of Instruction, 7(1).

Alonso, A. R. (2014). Teaching speaking: an exploratory study in two academic contexts. Porta Linguarum, 22.

Andújar-Vaca, A., \& Cruz-Martínez, M. S. (2017). Mobile instant messaging: Whatsapp and its potential to develop oral skills. Media Education Research Journal, 25(50), 43-52. https://doi.org/10.3916/C50- 2017-04

Anglano, C. (2014). Forensic analysis of WhatsApp Messenger on Android smartphones. Digital Investigation, 11(3), 201-213. https://doi.org/10.1016/j.diin.2014.04.003

Deshen, M., Buchnik, D., \& Brochson, S. (2014). Bar-Ilan University. Retrieved from http://meital.iucc.ac.il/conf2014/Meital_Conference_BL14_part_1.pdf

Dunlap, J. C. (2006). Using guided reflective journaling activities to capture students' changing perceptions. TechTrends, 50(6), 20-26. https://doi.org/10.1007/s11528-006-7614-X

Escobar, F., \& Arteta, I. (2020). WhatsApp for the development of oral and written communication skills in Peruvian adolescents. Comunicar. Media Education Research Journal, 65. Retrieved from https://www.revistacomunicar.com/index.php?\&idioma=en

Hamad, M. M. (2017). Using WhatsApp to enhance students' learning of English Language. Experience to share. Higher Education Studies Journal, 7(4). https://doi.org/10.5539/hes.v7n4p74

Khan, N., \& Ali, A. (2010). Improving the speaking ability in English: The students' perspective. Procedia Social and Behavioral Sciences, 2(2), 3575-3579. https://doi.org/10.1016/j.sbspro.2010.03.554 
Lam, Y., \& Lawrence, G. (2002). Teacher-student role redefinition during a computer-based second language project: Are computers catalysts for empowering change?. Computer Assisted Language Learning, 15(3), 295-315. https://doi.org/10.1076/call.15.3.295.8185

Laufer, B. (1998). The development of passive and active vocabulary in a second language: same or different?. Applied Linguistics, $19(2), \quad$ 255-271. https://doi.org/10.1093/applin/19.2.255

Laurillard, D. (2007). Pedagogical forms for mobile learning framing research question. In Framing research questions (pp. 153-175).

Maness, K. (2004). Teaching media-savvy students about the popular media. The English Journal, 93(3), 46-51. https://doi.org/10.2307/4128808

Minalla, A. A. (2018). The effect of WhatsApp chat group in enhancing EFL learners ${ }^{\text {ee }}$ verbal interaction outside classroom contexts. English Language Teaching, 11(3), 1-7. https://doi.org/10.5539/elt.v11n3p1

Montag, et al.. (2015). Smartphone usage in the 21st century: who is active on WhatsApp?. BMC Research Notes, 8(1), 331. https://doi.org/10.1186/s13104-015-1280-z

Mustafa, E. N. E. (2018). The Impact of YouTube, Skype and WhatsApp in improving EFL Learners' Speaking Skill. International Journal of Contemporary Applied Researches, 5(5), 2308-1365.

Rambe, P., \& Chipunza, C. (2013). Using mobile devices to leverage student access to collaboratively generated resources: A case of WhatsApp instant messaging at a South African university. International Conference on Advanced Information and Technology for Education. https://doi.org/10.2991/icaicte.2013.66

Riyanto, A. (2013, July). English language learning using WhatsApp application. AkhmadRianto, Love for All, Hatred for None. WordPress, the Splendid Theme.

Robles, H., \& Keogh, C. (2018). WhatsApp as a site for meaningful dialogue.

Sharples, M., Lonsdale, P., Meek, J., Rudman, P. D., \& Vavoula, G. N. (2007). An Evaluation of My Art Space: a Mobile Learning Service for School Museum Trips. In A. Norman, \& J. Pearce (Eds.), Proceedings of 6th Annual Conference on Mobile Learning, mLearn 2007, Melbourne. Melbourne: University of Melbourne (pp. 238-244).

Trentin, G., \& Repetto, M. (2013). Using network and mobile technology to bridge formal and informal learning. Elsevier. https://doi.org/10.1533/9781780633626

Uys, W., Mia, A., Jansen, G. F., Van, H., Leukes, N. A., Faltein, S., ... Gihwala, T. (2012). Smartphone application usage amongst students at a South African University.

Vaca, A. A. (2017). Mobile instant messaging: WhatsApp and its potential to develop oral skills. comunicar. Media Education Research Journal, 25(1). https://doi.org/10.3916/C50-2017-04 


\section{Macrothink}

International Journal of Linguistics

ISSN $1948-5425$ 2021, Vol. 13, No. 4

Vygotsky, L. S. (1978). Mind in society: The development of higher psychological processes. Cambridge: MA: Harvard University Press.

\section{Copyrights}

Copyright for this article is retained by the author(s), with first publication rights granted to the journal.

This is an open-access article distributed under the terms and conditions of the Creative Commons Attribution license (http://creativecommons.org/licenses/by/4.0/) 